\title{
RANCANGBANGUN PROGRAM KONTROL DATA LOGGER UNTUK PEMANTAUAN KUALITAS AIR MENGGUNAKAN APLIKASI FOSS GNU C++
}

\author{
Control Data Logger Program Development for Water Quality Monitoring Using FOSS GNU C++ Application
}

\author{
Oleh: \\ Heru Dwi Wahjono \\ Pusat Teknologi Lingkungan, BPPT
}

\begin{abstract}
Abstrak
Sistem pemantuan kualitas air realtime yang menggunakan mainboard komputer sebagai data loggernya membutuhkan aplikasi perangkat lunak yang berfungsi untuk mengendalikan kerja sensor dalam rangka pengambilan data kualitas air dan mengirimkannya ke pusat data. Beberapa persyaratan untuk pengukuran, penyimpanan dan pengiriman data serta peringatan dini diperlukan oleh data logger ini agar memiliki fitur seperti yang diinginkan oleh sebagian besar pengguna sistem ini. Unit sensor yang digunakan dipilih yang memiliki port komunikasi serial (RS232C) untuk mempermudah pembuatan kode program. Program kontrol data logger yang memenuhi persyaratan ini dibuat dengan menggunakan metode water flow software development life cycle dan dengan memanfaatkan aplikasi pengembangan berbasis free open source software (FOSS) GNU C++. Hasil pengembangannya kemudian diinstalasikan dan dioperasikan mengunakan sistem operasi FOSS FreeBSD yang dijalankan melalui perangkat USB flash disk kelas 10 berkapasitas 16 giga byte.
\end{abstract}

Kata Kunci: Pemantuan kualitas air, pemantauan online/realtime, sistem peringatan dini, perangkat lunak sumber terbuka, data logger, onlimo OSS, pengendali data logger, GNU C++

\begin{abstract}
Online and realtime monitoring system for water quality that uses a computer mainboard as data logger requires software applications that serve to control the sensor work in order to measure the water quality data and sends it to the data center. Some of the requirements such as data measurement, storage and delivery of data and early warning system are required by the data logger in order to have the features as desired by the majority of users of this system. To facilitate the making of the program code, sensor with serial communication ports (RS232C) will be used. Program control data logger that meets these requirements is developed using Water Flow Software Development Life Cycle method and using GNU C++ the free open source software (FOSS) as the development tools. Program control data logger that has been developed will be installed to the data logger hardware and operated using FreeBSD as the Operating system. The program will run on the class 10 of flash drive with 16 giga byte capacity.
\end{abstract}

Keywords: water quality monitoring, online/realtime monitoring, early warning system (EWS), open source software, data logger, onlimo OSS, control data logger, GNU C++

\section{PENDAHULUAN}

\subsection{Latar Belakang}

Pemantuan kualitas air untuk mengenda-likan pencemaran lingkungan telah dilakukan secara rutin oleh instansi pemerintah pusat maupun daerah. Kegiatan rutin pemantauannya dilakukan secara manual dengan mengambil sampling air pada beberapa periode waktu tertentu dan menganalisakannya ke laboratorium lingkungan. Walaupun kegiatan pemantuan ini telah dilakukan sejak lama, namun bencana pecemaran lingkungan perairan selalu berulang dan menimbulkan kerugian yang tidak sedikit, misalnya kejadian kematian masal ikan di teluk Jakarta pada tahun 2004 dan 2005 yang dikenal dengan blooming algae red tide(Gambar 1), sebagai akibat tingginya kadar nutrien yang mengakibatkan penurunan dissolve oxygen (DO) pada saat itu (Suhendar dan Wahjono,2007).

Untuk mencegah terulangnya kejadian ini diperlukan metode pemantuan secara kontinyu dengan bantuan sistem peralatan data logger untuk pengukuran kualitas air otomatis yang dikenal dengan nama online/realtime monitoring kualitas air. Sistem pengukuran kualitas air menggunakan data 
logger biasanya memiliki fitur peringatan dini, sehingga penurunan kualitas air dapat dipantau setiap saat dan pelanggaran terhadap salah satu parameter kualitas air dapat diberikan suatu peringatan dini kepada operator atau kepada pimpinan institusi/lembaga terkait. Peringatan dini dapat diberikan dalam berbagai bentuk seperti pesan singkat/SMS, bunyi sirine dan grafik analisa penurunan kualitas.

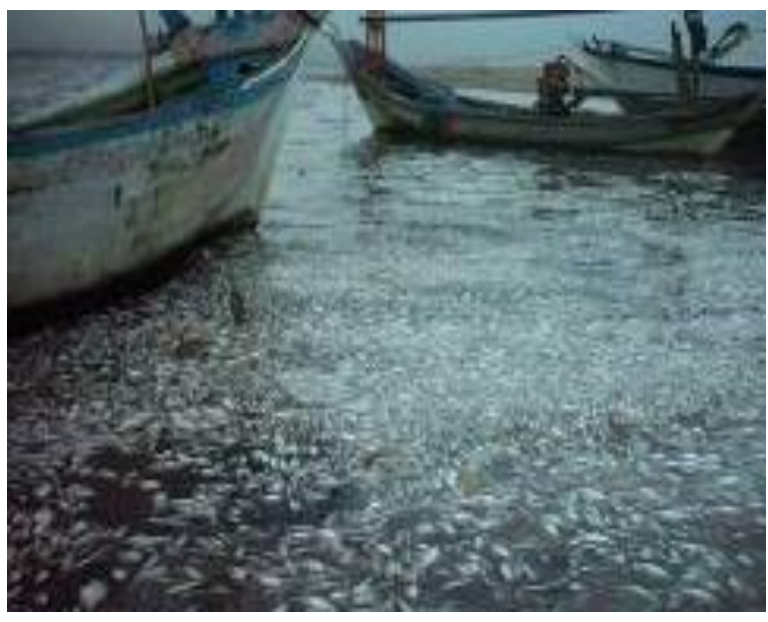

Gambar 1. Blooming Algae Red Tide.

Mahalnya produk impor peralatan data logger dan sensornya, serta sedikitnya produk lokal merupakan salah satu dari beberapa alasan belum diaplikasikannya teknologi ini untuk mendukung kegiatan pengendalian pencemaran lingkungan oleh instansi terkait. Oleh karena itu diperlukan suatu pengembangan sistem online monitoring yang memanfaatkan perangkat mainboard komputer sebagai data loggernya. Selain banyak terdapat di pasaran harganya pun juga relatif murah dan dapat dengan mudah dirakit untuk menjadi sebuah data logger pemantuan kualitas air online dan realtime. Untuk mengoperasikannya diperlukan pengembangan aplikasi perangkat lunak kontrol data logger yang mengendalikan kerja sensor dalam pengukuran kualitas air secara kontinyu.

\subsection{Tujuan dan Sasaran}

Kegiatan ini bertujuan untuk melakukan perancangan dan pengembangan sebuah aplikasi perangkat lunak kontrol data logger menggunakan free open source software (FOSS) GNU C++ dengan source code bahasa $C$. Sedangkan sasarannya adalah terciptanya program control data logger yang memiliki beberapa fitur yang dibutuhkan oleh sebuah sistem pemantauan kualitas air.

\section{LINGKUP DAN METODOLOGI KEGIATAN}

Lingkup kegiatan rancang bangun program control data logger pemantauan kualitas air ini meliputi :

- Perancangan algoritma program sesuai fitur yang dibutuhkan pengguna.

- Pembuatan kode program menggunakan GNU C++ yang dapat dioperasikan pada sistem operasi FreeBSD.

- Pengujian program pada data logger berbasis mainboard komputer.

- Pembuatan dokumentasi SOP atau petunjuk penggunaan program kontrol data logger.

Adapun metodologi yang digunakan untuk pengembangan aplikasi ini adalah metode water flow software development life cycle (SDLC) yang terdiri dari langkah-langkah sebagai berikut :

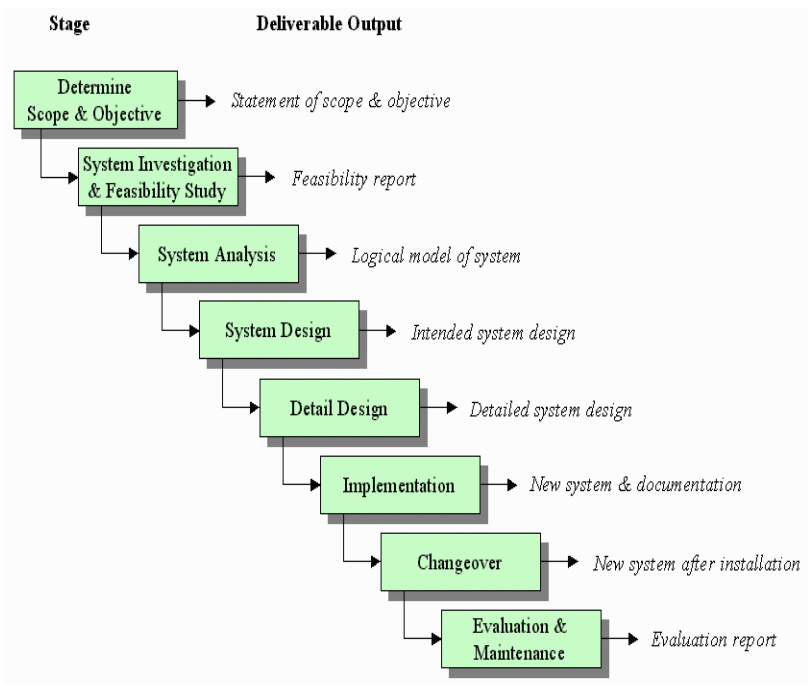

Gambar 2. Waterfall Model Software Development Live Cylce (Curtis, 1995)

Setiap tahapan metodologi di atas menghasilkan keluaran yang dapat dijadikan sebagai masukan untuk langkah berikutnya. Untuk perbaikan dan penyempurnaan algoritma sistem program, pada metode ini dimungkinkan kembali ke langkah sebelumnya secara berulang sampai didapatkan keluaran yang benar-benar sesuai dengan kebutuhan pengguna (Curtis, 1995).

\section{PEMBAHASAN}

\subsection{Metode Pengambilan Data}

Kegiatan pemantauan kualitas air online dan realtime merupakan kegiatan telemetri (tele: jarak jauh, metri: pengukuran). Metode ini memiliki tiga macam pengambilan data, yaitu: (Syamsudin,1984) 
1) Time Base Telemetri, yaitupengiriman data yang digerakkan oleh waktu.

2) Polling Base Telemetri, yaitupengiriman data yang digerakkan oleh sebuah perintah dari pusat data.

3) Event Base Telemetri, yaitupengiriman data yang digerakan oleh adanya kejadian peristiwa atas perubahan salah satu parameter pemantauan.

Data logger yang dirakit menggunakan mainboard komputer sebagai alternatif teknologi pemantauan kualitas air online dan realtime dikembangkan agar mampu melakukan tiga metode pengambilan data di atas. Kombinasi ketiga metode ini dapat diwujudkan dalam sebuah program control data logger yang dibuat menggunakan bahasa pemrograman $\mathrm{C}++$.

\subsection{Multi Probe Sensor}

Perkembangan teknologi sensor saat ini memungkinkan pengguna untuk melakukan pengukuran beberapa parameter sekaligus dalam satu waktu secara mudah. Teknologi multi probe sensor memungkinkan pemasangan beberapa probe parameter kualitas air yang bersifat electro chemical pada sebuah casing sensor. Beberapa parameter electro-chemical,yang dapat diukur yaitu (Hungarian Ministry, 1996) :

Tabel 1. Parameter Electro Chemical Sensor.

\begin{tabular}{|ll|c|c|}
\hline \multicolumn{2}{|c|}{ Parameter } & Satuan & Baku Mutu \\
\hline 1. & Dissolved Oxygen & $\mathrm{mg} / \mathrm{l}$ & $0-20$ \\
\hline 2. & Turbidity & $\mathrm{NTU}$ & $0-500$ \\
\hline 3. & Conductivity & $\mu \mathrm{S} / \mathrm{cm}$ & $0-2000$ \\
\hline 4. & Temperatur & $\mathrm{C}^{\circ}$ & $0-50$ \\
\hline 5. & $\mathrm{pH}$ & & $0-14$ \\
\hline 6. & Ammonium ion & $\mathrm{mg} / \mathrm{l}$ & $0-10$ \\
\hline 7. & TOC & $\mathrm{mg} / \mathrm{l}$ & $0-20$ \\
\hline 8. & Floating oil & - & - \\
\hline 9. & Chlorofyll-a & $\mu \mathrm{g} / \mathrm{l}$ & $0,1<$ \\
\hline 10. & Biomonitor & $\mathrm{Index} \mathrm{T}$ & $0-15$ \\
\hline
\end{tabular}

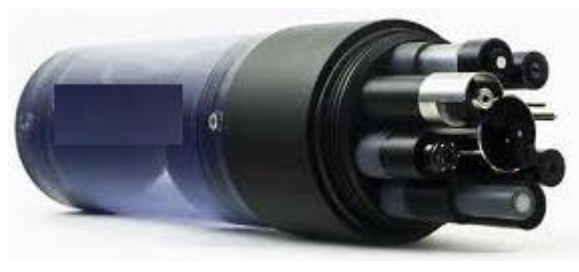

Gambar 3. Digital Multi Probe Sensor (YSI, 2011)

Konektifitas pada unit data logger melalui konektor serial RS232C atau USB yang terdapat pada mainboard komputer seperti pada gambar di bawah ini (Anonymous, 2012).

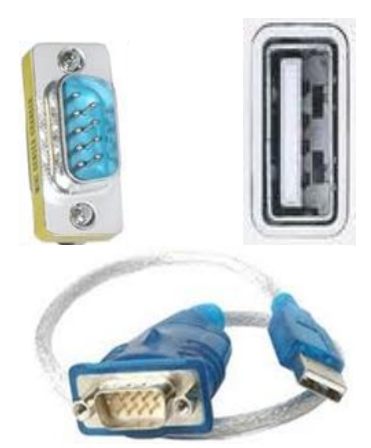

Gambar 4. Konektor Serial RS232C, USB dan Kabel USB to Serial Converter.

Pemasangan konektor serial RS232C unit sensor ke konektor USB pada mainboard komputer dilakukan dengan bantuan kabel USB to serial converter. Spesifikasi teknis unit sensor yang digunakan adalah sebagai berikut (YSI, 2011) :
- Output data
: analog/digital(4-20mA)
- Koneksi PC
: RS232C atau RS485C
- Data speed
: $1.200 \sim 11.520$ bps
- Probe
: single atau multi
- Info lokasi
: GPS
- Memori
- Data logging
: Internal flash memory
- Logging interval
: cyclic atau noncyclic
: 1 86.400 detik

\subsection{Data Logger Berbasis Mainboard PC}

Unit data logger berbasis mainboard $\mathrm{PC} /$ komputer merupakan remote terminal unit (RTU) yang berfungsi untuk pengambilan data kualitas air di lapangan menurut parameter setting yang telah ditetapkan. Data logger berbasis mainboard PC memiliki komponen CPU, memori dan program control data logger yang mengendalikan proses kerja komponennya. Data logger dihubungkan dengan unit sensor untuk mengukur data kualitas air dan media komunikasi untuk mengirimkan data ke pusat data.

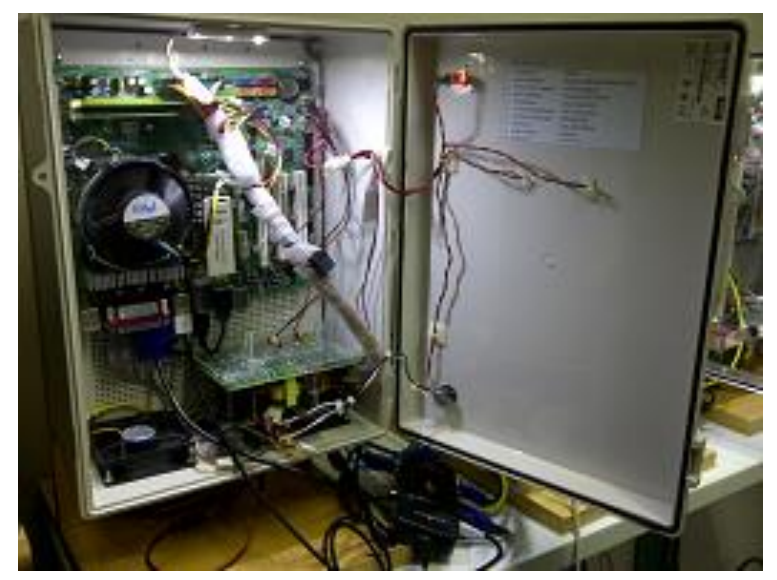

Gambar 5. Data Logger Berbasis Mainboard PC. 
Spesifikasi teknis data logger yang dibuat menggunakan mainboard komputer adalah sebagai berikut (Wahjono, 2012) :

- Mainboard:

- Tipe : Micro ATX atau Lebih Kecil

- Dimensi : $25 \mathrm{~cm} \times 25 \mathrm{~cm}$

- Fitur BIOS : Bootable USB Flash Disk

- Memiliki Minimal 2 Port USB dan 1 Serial $\mathrm{RS} 232 \mathrm{C}$

- Processor : AMD/Intel Pentium III, IV atau di atasnya

- Memory : Minimal 512 MB, Optimal 1 GB

- Media : 16GB USB Highspeed Flash Diskatau kelas 10 (>30 MB/S)

- Komunikasi : USB Wifi Adaptor (TP Link W321G)

- Power Suplai :

- Tipe : ATX 12 Volt

- Input : AC 220/110V 50/60Hz (<380 Watt)

- Output Arus AC : 2,5 5 Ampere

- Output VDC : $3,3 \mathrm{~V},+5 \mathrm{~V},+12 \mathrm{~V},-5 \mathrm{~V},-12 \mathrm{~V}$, $+5 \mathrm{VSB}$

- Output CDC: 16A,30A,14A,0.5A,0.5A,2.5A

- Pengaman : Fuse f6.3A 250 VAC

- Dimensi Box Panel : LxTxD = 30cmx40cmx16 cm

- Bahan Box Panel : Plastik Ketebalan $1 \mathrm{~mm}$

- Pendingin : Double Reverse Van (12V 0,2A)

\subsection{Program Control Data Logger}

Program control data logger adalah sebuah aplikasi perangkat lunak yang diperlukan untuk mengendalikan proses pengukuran kualitas air oleh data logger menggunakan multi probe sensor berdasarkan setting tertentu. Program control data logger ini bekerja di dalam sistem operasi FreeBSD yang keduanya diinstalasikan pada media penyimpan data berupa USB Flash Disk. Sistem operasi FreeBSD merupakan FOSS yang dapat diunduh dari situs www.freebsd.org, sedangkan program control data logger dikembangkan menggunakan FOSS untuk data logger berbasis mainboard komputer.

Beberapa aplikasi FOSS yang diperlukan untuk melakukan pengembangan program control data logger adalah :

- Aplikasi text editor untuk menyunting kode sumber (source code) program yang dikembangkan.

- GNU compiler CPP/C++ untuk mengkompilasi (mengubah ke bahasa mesin program yang dikembangkan sehingga bisa diekseskui).

- Debugger untuk melakukan debug (eksekusi program secara bertahap untuk mendeteksi adanya kesalahan program.

- Kermit untuk melakukan koneksi secara manual ke unit sensor melalui konektor serial RS232C yang berguna untuk menganalisa karakteristik multiprobe sensor kualitas air yang digunakan.

\subsubsection{Perancangan Algoritma}

Algoritma program control data logger dirancang sesuai dengan kebutuhan pengguna agar memiliki beberapa fitur yang diinginkan, di antaranya adalah sebagai berikut:

- Program dapat dijalankan secara manual dan otomatis baik secara proses background maupun proses foreground.

- $\quad$ Program memiliki beberapa opsi eksekusi, yaitu :

$>$ [Serial], untuk menentukan nama file device koneksi serial ke sensor.

$>$ [Baudrate], untuk menentukan kecepatan komunikasi data.

$>$ [ID]. untuk menset nomor identifikasi stasiun data logger.

$>\quad$ [Waktu], untuk menentukan interval waktu pengambilan data periodik.

$>$ [Fdata], untuk menentukan nama file ASCII/teks data pengukuran.

$>$ [Opsi -f], untuk menjalankan program secara proses foreground.

$>[$ Opsi $-\mathrm{v}]$, untuk mengaktifkan mode verbose

- Program dapat dieksekusi lebih dari satu kali proses, sehingga dapat digunakan untuk mengoperasikan lebih dari satu multi probe sensor.

- Metode akses (cara menjalankan program) yang diinginkan adalah:

\# program Serial Baudrate ID Waktu Fdata
Opsi
atau
\# program filekonfigurasi

Contoh:

\# onlimo /dev/com0 9600 DL1 600
filedata.txt -v
atau
\# onlimo /home/onlimo/bin/onlimo.conf

Artinya adalah yang pertama program control data logger bernama file 'onlimo' yang dihubungkan ke sensor melalui file device '/dev/com0' dengan kecepatan transmisi '9600' bps,akan melakukan pengukuran data untuk nomor identifikasi data logger 'DL1' dan menyimpan hasil pengukurannya ke dalam 'filedata.txt', dan berjalan dalam mode 'verbose' untuk melihat hasilnya di layar monitor. Yang kedua berarti program 'onlimo' dijalankan dengan parameter setting yang tersimpan di dalam file konfigurasi 'onlimo.conf' yang berada di dalam direktori '/home/onlimo/bin'. 
- Program yang dieksekusi secara foreground menampilkan informasi konfigurasi setting dan beberapa baris hasil pengukurannya ke layar monitor.

- Program dapat dimodifikasi sesuai kebutuhan pengguna, sehingga pencatatan versi dan perubahan setiap versi perlu dilakukan.

- Program dapat dikompilasi pada sistem Unix FreeBSD dan Ubuntu dengan mudah, sehingga perlu dibuatkan mekanisme kompilasi menggunakan 'Makefile' yang fleksibel di kedua sistem operasi tersebut.

- Setting parameter yang dibutuhkan oleh software untuk beroperasi dapat diletakkan di dalam file konfigurasi 'onlimo.conf' dengan setting parameter sebagai berikut (Wahjono, 2012) :

\begin{tabular}{|c|c|}
\hline comport= /dev/ttyU0 & \# file port komunikasi \\
\hline baudrate $=9600$ & \# kecepatan koneksi data \\
\hline idstasiun = SB1 & \# nomor ID stasiun \\
\hline twarning $=60$ & \# interval data EWS (detik) \\
\hline tperiodik $=600$ & \# interval data periodik (sec) \\
\hline mysqldb = onlimodb & \# nama database MySQL \\
\hline mysqltable= Pengukuran & \# table database \\
\hline ipaddress $=192.168 .0 .100$ & \# ip address MySQL \\
\hline username $=$ root & \# MySQL user name \\
\hline password = 1234 & \# MySQL password \\
\hline filelog= monitoring.log & \# nama file pesan error \\
\hline datatxt= Pengukuran.txt & \# nama file text data \\
\hline BMSUHU $=25,00 \quad 32,00$ & \# range baku mutu suhu \\
\hline $\mathrm{BMDHL}=10,00 \quad 20,00$ & \# range BM conductifity \\
\hline $\mathrm{BMTDS}=10,00 \quad 15,00$ & \# range $\mathrm{BM}$ TDS \\
\hline $\mathrm{BMSAL}=10,00 \quad 15,00$ & \# range $\mathrm{BM}$ kadar garam \\
\hline $\mathrm{BMDO}=05,00 \quad 06,00$ & $\#$ range $\mathrm{BM} \mathrm{O}_{2}$ terlarut \\
\hline $\mathrm{BMPH}=06,50 \quad 07,05$ & \# range $\mathrm{BM} \mathrm{pH}$ \\
\hline
\end{tabular}

Selain fitur yang dibutuhkan di atas, algoritma program dirancang juga berdasarkan cara kerja sistem software yang diinginkan, yaitu sebagai berikut :

- Program melakukan koneksi ke sensor dan mengambil data pengukuran sesuai interval waktu yang ditentukan, lalu menyimpannya ke dalam database di pusat data.

- Ada dua interval waktu yang diberikan, yaitu interval waktu periodik dan interval waktu peringatan dini (early warning system) / EWS. Interval waktu periodik harus lebih panjang daripada interval waktu EWS.

- Program akan melakukan pengukuran sesuai interval waktu EWS secara kontinyu, apabila data yang diperoleh tidak melampaui baku mutunya, maka data akan diabaikan (tidak disimpan), tetapi jika data yang diperoleh melampaui bakumutu, maka data disimpan.

- Program juga akan melakukan pengukuran sesuai interval waktu periodik secara kontinyu pula dan mengirimkan hasil pengukurannya ke pusat data.

- Apabila komputer server sebagai pusat data tidak dapat dihubungi dan data logger gagal mengirimkan data ke komputer server, maka data logger menuliskan data pengukuran tersebut ke dalam local file 'pengukuran.txt', sehingga dapat digabungkan kemudian.

- Jika program control data logger tidak dapat berkomunikasi ke sensor maka program harus menuliskan pesan error ke dalam file log untuk keperluan penelusuran kesalahan.

- Apabila program control data logger tidak dapat mengirimkan datanya ke komputer server, maka program juga harus menuliskan pesan error ke dalam file log untuk keperluan penelusuran kesalahan juga.

- Data pengukuran yang masuk ke dalam komputer server dikelola sedemikian rupa, sehingga dengan bantuan GUI berbasis web dapat ditelusuri kembali dalam bentuk angka maupun grafik analisa.

Dari kedua fitur dan cara kerja sistem perangkat lunaknya, maka alur kerja program control data logger dapat dilihat seperti pada flow diagram Gambar 6 di bawah ini.

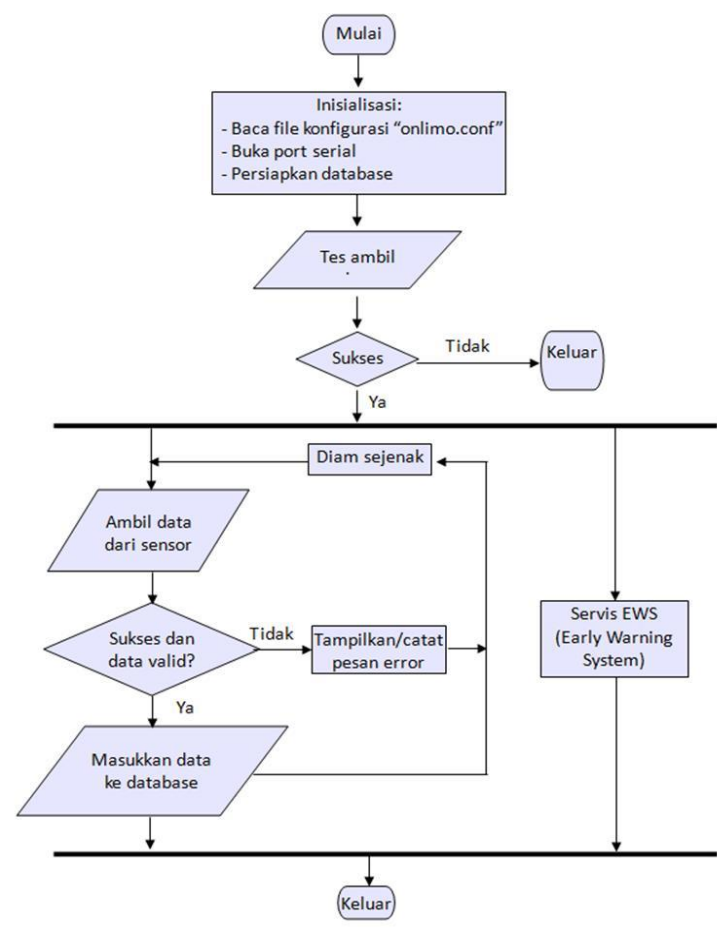

Gambar 6 : Flow Diagram Program Control Data Logger (Wahjono, 2012) 


\subsubsection{Pemrograman Kode Sumber}

Kode sumber yang digunakan untuk mengembangkan program control data logger adalah bahasa $\mathrm{C}++$. Untuk mempermudah proses identifikasi kode program yang dikembangkan diberikan penomoran versi pada kode sumber yang telah dikembangkan dan diujicobakan secara offline. Versi mayor dengan perubahan besar diberikan dengan dua digit angka, sedangkan versi minor dengan perubahan kecil diberikan dalam tiga digit angka. Berikut ini adalah tabel versi pengembangan program control data logger dengan masing-masing perubahan di dalamnya.

Tabel 2 : Perkembangan Versi Program Control Data Logger (TPABLC, 2012)

\begin{tabular}{|c|c|}
\hline Versi & Perubahan \\
\hline 1.0 & $\begin{array}{l}\text { - Release pertama dengan fitur berupa } \\
\text { pengambilan data dari sensor dan } \\
\text { mencatatkannya ke dalam file teks. } \\
\text { - Release kedua berisi pengurangan interval } \\
\text { pengambilan data ketika program sedang } \\
\text { dalam proses persiapan. } \\
\text { - Release ketiga berisi penambahan opsi } \\
\text { menjalankan program sebagai background } \\
\text { process atau berjalan di terminal. }\end{array}$ \\
\hline 1.1 & $\begin{array}{l}\text { - Membaca parameter setting dari file } \\
\text { onlimo.conf } \\
\text { - Mencatat pesan error ke file } \\
\text { monitoring.log } \\
\text { - Penambahan fitur peringatan dini }\end{array}$ \\
\hline 1.2 & $\begin{array}{l}\text { Data dari sensor tidak lagi dicatat ke file } \\
\text { teks, tetapi dimasukkan ke dalam database } \\
\text { MySQL }\end{array}$ \\
\hline 1.2 .1 & $\begin{array}{l}\text { Tidak ada perubahan dari versi 1.2. Hanya } \\
\text { disertakan satu program lagi berupa } \\
\text { simulator. Release selanjutnya selalu } \\
\text { menyertakan simulator. }\end{array}$ \\
\hline 1.3 & $\begin{array}{l}\text { Tidak ada perubahan dari versi 1.2. Hanya } \\
\text { penambahan komentar pada source code } \\
\text { untuk menjelaskan masing-masing fungsi. }\end{array}$ \\
\hline 1.4 & $\begin{array}{l}\text { - Alamat file config bisa diubah, tidak harus } \\
\text { berada pada satu folder dengan program } \\
\text { - Interval pengambilan data dibuat lebih } \\
\text { akurat }\end{array}$ \\
\hline 1.5 & $\begin{array}{l}\text { Perbaikan bug: } \\
\text { - Program dijalankan } 2 \text { kali agar bisa jalan. } \\
\text { - Program terlalu banyak mengambil data } \\
\text { dalam interval } 1 \text { detik. } \\
\text { - Data yang diambil terkadang tidak lengkap } \\
\text { (jumlah data } \neq 6) \text {. } \\
\text { - Penulisan pesan error terlalu banyak, } \\
\text { sehingga dipersingkat. } \\
\text { - Format penulisan tanggal berbeda. }\end{array}$ \\
\hline
\end{tabular}

\begin{tabular}{|l|l|}
\hline 1.5 .1 & $\begin{array}{l}\text { Perbaikan bug saat menghentikan program, } \\
\text { terkadang harus menunggu hingga timer } \\
\text { pengambilan data berakhir }\end{array}$ \\
\hline 1.5 .2 & $\begin{array}{l}\text { Sebelum mengirim perintah "data<enter>", } \\
\text { diawali dengan pengiriman kode <enter> } \\
\text { terlebih dulu }\end{array}$ \\
\hline 1.6 & Fitur reconnect jika MySQL server mati \\
\hline 1.7 & $\begin{array}{l}\text { - Perbaikan fungsi untuk memasukkan data } \\
\text { ke dalam database MySQL ketika koneksi } \\
\text { putus, yaitu penambahan } \\
\text { mysql_select_db() untuk memilih kembali } \\
\text { database }\end{array}$ \\
& $\begin{array}{l}\text { - Perubahan syntax query pembuatan tabel } \\
\text { MySQL }\end{array}$ \\
& $\begin{array}{l}\text { Buffer port serial dibersihkan terlebih } \\
\text { dahulu setiap kali akan mengambil data } \\
\text { dari sensor } \\
\text { - Perbaikan fungsi untuk menghentikan } \\
\text { program }\end{array}$ \\
\hline 1.8 & $\begin{array}{l}\text { - Perbaikan fungsi pengambilan data } \\
\text { - Buffer serial tidak akan dibersihkan } \\
\text { terlebih dahulu pada saat akan mengambil } \\
\text { data dari sensor } \\
\text { Bila pencatatan data ke dalam database } \\
\text { MySQL gagal, data akan dicatat ke dalam } \\
\text { sebuah file teks }\end{array}$ \\
\hline
\end{tabular}

Program control data logger diberikan nama 'onlimo' singkatan dari 'online monitoring' dengan versi di belakangnya, misalnya onlimo18 yang berarti program online monitoring versi 1.8. Kode sumber setiap versinya diletakkan ke dalam sebuah direktori yang diberi nama sama, misalnya 'Onlimo1.8/'. Sejak versi 1.2.1, onlimo dibuat dalam dua sub versi, yaitu sub versi 'OnlimoDataLogger' dan sub versi simulatornya, yaitu 'OnlimoDataLogger_simulator'.

Sub versi OnlimoDataLogger' digunakan untuk pengambilan data ke unit sensor, sedangkan sub versi simulatornya digunakan untuk pengambilan data tanpa sensor dengan data dummy sebagai hasil pengukurannya. Prinsip kerja sub versi simulator adalah sama dengan sub versi sesungguhnya, hanya pada saat program tidak mendapatkan respon dari unit sensor, maka sub routine data generator di dalam program onlimo akan memberikan data secara acak sebagai data dummy hasil pengukuran. Sehingga seolah-olah program onlimo berhasil berkomunikasi dengan unit multiprobe sensor.

Kedua sub versi dibuat agar dapat dikompilasi pada sistem operasi FreeBSD maupun Linux Ubuntu menggunakan perintah standar kompilasi 'make' dengan mendifinisikan parameternya pada file konfigurasi 'Makefiles'. Tabel berikut ini adalah daftar file yang dihasilkan pada pengembangan program control data logger onlimo versi 1.8, yaitu : 
Tabel 3 : File Kode Sumber Program Control Data Logger (TPABLC, 2012)

\begin{tabular}{|c|c|}
\hline File & Keterangan \\
\hline Makefile & $\begin{array}{l}\text { file definisi untuk program } \\
\text { kompiler make }\end{array}$ \\
\hline main.cpp & $\begin{array}{l}\text { program utama yang } \\
\text { mereferensi semua kode } \\
\text { sumber program .cpp dan } \\
\text { header .h }\end{array}$ \\
\hline $\begin{array}{l}\text { ConfigHandler.h } \\
\text { ConfigHandler.cpp }\end{array}$ & $\begin{array}{l}\text { Berisi kelas pembacaan data } \\
\text { dari file onlimo.conf dengan } \\
\text { format: } \\
<\text { nama_parameter }>=<\text { data }>\# \\
\text { komentar } \\
<\text { nama_parameter }>= \\
<\text { data1 }><\text { delimiters }><\text { data2 }> \\
\text { contoh: } \\
\text { comport }=/ \text { dev } / \text { tty } 0 \\
\text { BMSUHU }=25,00 \quad 32,00\end{array}$ \\
\hline $\begin{array}{l}\text { DbManager.h } \\
\text { DbManager.cpp }\end{array}$ & $\begin{array}{l}\text { Berisi kelas untuk menangani } \\
\text { operasi penulisan data ke dalam } \\
\text { database MySQL server. }\end{array}$ \\
\hline $\begin{array}{l}\text { SensorLogger.h } \\
\text { SensorLogger.cpp }\end{array}$ & $\begin{array}{l}\text { Berisi kelas utama yang } \\
\text { bertugas melakukan } \\
\text { pengambilan data dan } \\
\text { mencatatkannya ke dalam } \\
\text { database. }\end{array}$ \\
\hline $\begin{array}{l}\text { SerialStream.h } \\
\text { SerialStream.cpp }\end{array}$ & $\begin{array}{l}\text { Kelas yang menangani operasi } \\
\text { terhadap serial port, seperti } \\
\text { membuka port, menutupnya, } \\
\text { membaca data, dan menulis } \\
\text { data. }\end{array}$ \\
\hline onlimo.conf & $\begin{array}{l}\text { File konfigurasi setting } \\
\text { parameter eksekusi }\end{array}$ \\
\hline
\end{tabular}

File-file kode sumber program control data logger yang dihasilkan pada kegiatan pemrograman secara keseluruhan terdiri dari kurang lebih 5500 baris kode sumber. Untuk mengkompilasi semua file kode sumber di atas digunakan perintah GNU 'make' yang akan menghasilkan file obyek dari setiap kelompok kode sumber, yaitu:

- ConfigHandler.h dan ConfigHandler.cpp akan membentuk ConfigHandler.o

- DbManager.h dan DbManager.cpp akan membentuk DbManager.o, dan seterusnya.

Kemudian masing-masing file obyek akan dijadikan satu menjadi satu program yang dapat dieksekusi mewakili program control data logger. Berikut ini adalah isi dari konfigurasi file Makefile.

\footnotetext{
project $=$ onlimo

$\mathrm{CXX}=\mathrm{g}++$

CFLAGS = -1/usr/include/mysql $-1 /$ usr/local/include/mysq

LDFLAGS $=-$ L/usr/lib/mysql - L/usr/local/lib/mysql

LIBS = -Ipthread -Irt -Imysqlclient

all: \$(project)

clean:

rm -f ConfigHandler.o SerialStream.o DbManager.o SensorLogger.o main.o \$(project)
}

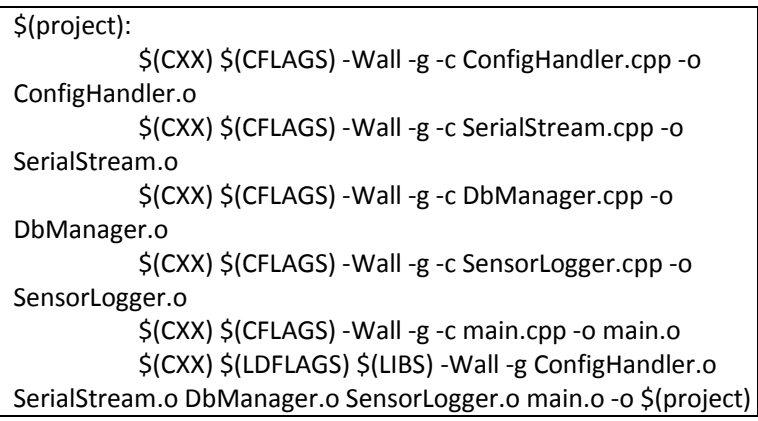

Konfigurasi Makefile seperti contoh di atas menghasilkan keluaran program 'onlimo' yang dapat dieksekusi melalui shell prompt sistem operasi FreeBSD. Berikut ini adalah hasil eksekusi program control data logger 'onlimo' :

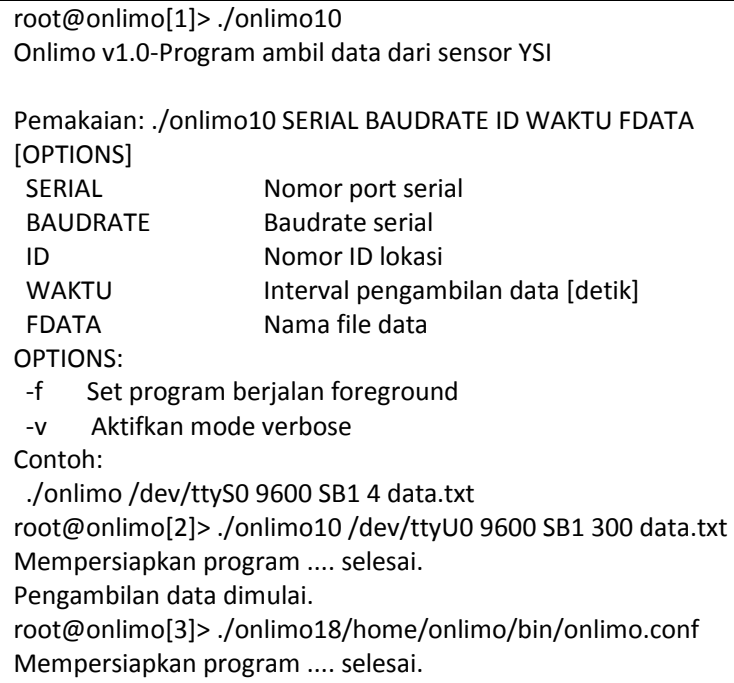

Pada contoh di atas, program control data logger 'onlimo10' dijalankan untuk mengendalikan sensor pada data logger dengan ID 'SB1' yang terhubung melalui device file '/dev/ttyUo' dan kecepatan akses '9600 bps'. Interval waktu pengambilan datanya adalah 300 detik dengan file penyimpanan datanya adalah 'data.txt'. Sedangkan pada contoh berikutnya, program control data logger 'onlimo18' dijalankan dengan menggunakan parameter setting pada file konfigurasi '/home/onlimo/bin/onlimo.conf'.

Jika pada versi 1.0 data pengukuran disimpan pada file teks, maka pada versi 1.8 data disimpan dalam data base server dengan alamat IP yang ditentukan oleh variabel 'ipaddress' dan database yang ditentukan oleh variabel 'mysqldb' dan 'mysqltable', serta file teks yang ditentukan oleh variabel 'datatxt' dalam file konfigurasi onlimo.conf. Interval waktu pengukuran data periodik ditentukan oleh variabel 'tperiodik' dan interval waktu pengukuran data EWS ditentukan oleh variabel 'twarning'. 


\subsubsection{Metode Pengiriman Data}

Metode pengiriman data pengukuran online melalui data logger berbasis mainboard komputer ini menggunakan protocol TCP/IP. Oleh karena itu diperlukan topologi jaringan intranet berbasis TCP/IP. Media yang digunakan dapat menggunakan kabel (UTP : Unshielded Twisted Pair) atau tanpa kabel. Pada data logger berbasis mainboard yang dikembangkan ini menggunakan USB Wifi Adaptor sebagai media komunikasi tanpa kabel berbasis TCP/IP (Gambar 7).
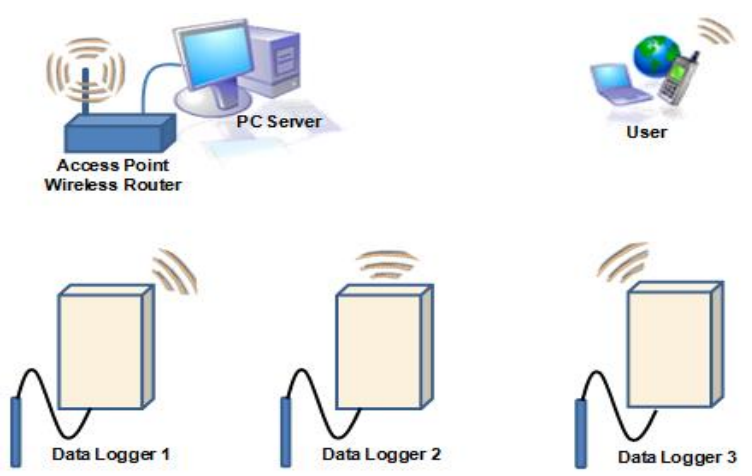

Gambar 7. Topologi Jaringan TCP/IP Untuk Komunikasi Data Logger

Pada topologi seperti ini luas jangkauan perangkat data logger dan komputer sangat bergantung kepada spesifikasi teknis dari perangkat USB wifi adaptor yang ada di masing-masing data logger dan access point (AP) atau perangkat wireless router yang digunakan. Untuk memperluas jangkauan komunikasi topologi seperti ini dapat digunakan perangkat wireless ekstender sesuai spesifikasi yang diinginkan.

Tidak semua perangkat USB wifi adaptor dapat digunakan sebagai media komunikasi dalam pengembangan data logger berbasis mainboard komputer ini. Walaupun sistem operasi memiliki banyak daftar perangkat USB wifi adaptor yang didukungnya, namun hanya beberapa saja yang tersedia di pasaran di tanah air, yaitu TP-LINK TLWN321G (versi 2.0 4.1) dan D-Link DWA-140 seperti Gambar 8 berikut :
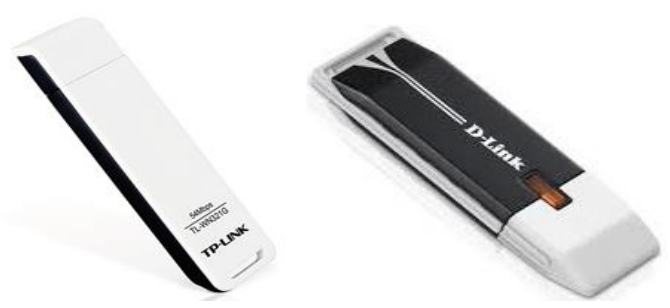

Gambar 8 : Media Komunikasi Data Yang Didukung Oleh FreeBSD.
Kedua media komunikasi ini memiliki chipset yang sama, yaitu Ralink dan kecepatan transmisi wireless nya adalah $54 \mathrm{Mbs}$ dengan onboard no-gain antenna.

Melalui media komunikasi USB wifi adaptor ini dilakukan metode pengiriman data dengan algoritma pemrograman seperti pada flow diagram Gambar 9.

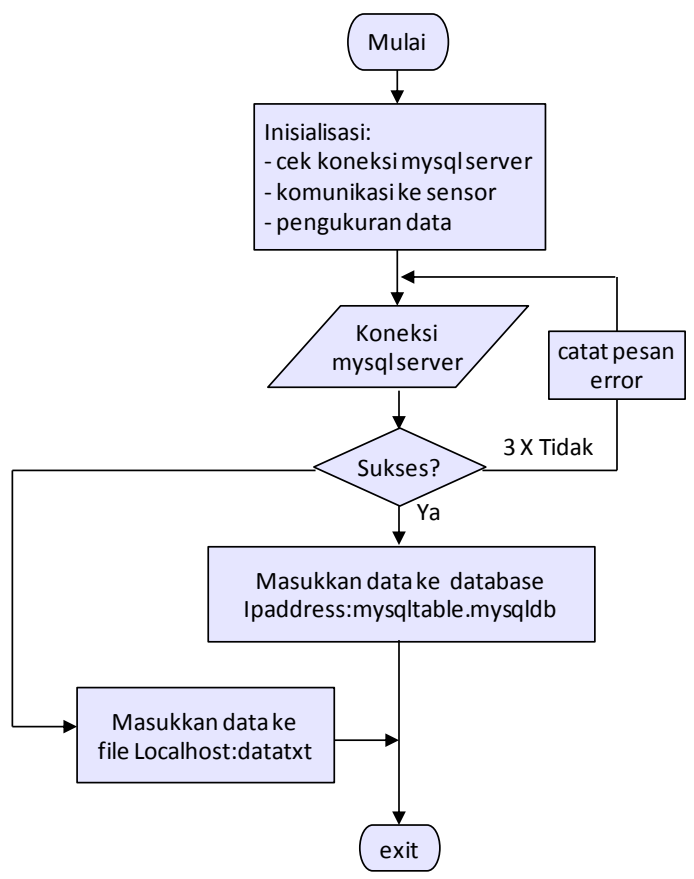

Gambar 9. Flow Diagram Algoritma Pengiriman Data.

- $\quad$ Saat data logger mulai beroperasi, sistem operasi FreeBSD akan memastikan USB wifi adaptor tersambung pada jaringan intranet yang telah ditentukan.

- Pada akhir proses booting data logger, sistem operasi FreeBSD akan menjalankan program control data logger 'onlimo18' dengan parameter setting yang berada pada file 'onlimo.conf'.

- Di dalam file onlimo.conf ini terdapat setting variabel yang diperlukan untuk proses pengiriman dan pencatatan data dalam file data, yakni :

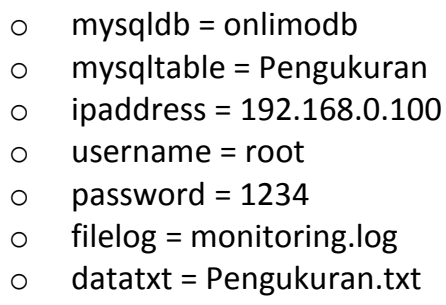

- Data yang diperoleh oleh sensor selanjutnya dikirimkan oleh program control data logger ke server (ipaddress $=192.168 .0 .100$ ) dan dicatat ke dalam tabel data (mysqltable $=$ Pengukuran) $\mathrm{di}$ dalam file database (mysqldb = onlimodb) sesuai otoritas akses (username $=$ root, password = 1234) 
- Jika, karena sesuatu hal komunikasi ke komputer server atau komunikasi ke Mysql server tidak berhasil, maka program kontrol data logger menyimpan data pengukuran ke dalam file lokal 'datatxt = Pengukuran.$t x t$ '.

\subsubsection{Pengujian Program}

Software test untul program control data logger yang telah dikembangkan, dilakukan dengan menginstalasikannya pada unit data logger berbasis mainboard PC yang telah diinstalasikan sistem operasi FreeBSD. Data logger disetting sedemikian rupa sehingga dapat berjalan secara otomatis saat saklar listrik dinyalakan. Proses startup/booting data logger dapat dilihat melalui layar monitor, sehingga kegagalan program dapat diketahui dan dianalisa penyebabnya. Beberapa hal yang perlu disiapkan untuk pengujian program control data logger adalah sebagai berikut :

- Instalasi dan konfigurasi FreeBSD, MySQL Server, Apache Server, serta koneksi intranetpada komputer server dengan kapasitas hard disk drive 80GB. Layout pembagian partisinya seperti contoh berikut :

$\begin{array}{llll}\circ & \text { Partisi } & \text { / } & 5.0 \mathrm{~GB} \\ \circ & \text { Partisi } & \text { /var } & 5.0 \mathrm{~GB} \\ \circ & \text { Partisi } & \text { /tmp } & 2.0 \mathrm{~GB} \\ \circ & \text { Partisi } & \text { /home } & 10.0 \mathrm{~GB} \\ \circ & \text { Partisi } & \text { swap } & 4.0 \mathrm{~GB} \\ \circ & \text { Partisi } & \text { /usr } & 48.0 \mathrm{~GB}\end{array}$

- Spesifikasi teknis komputer server yang digunakan adalah sebagai beriktu :

$$
\begin{array}{ll}
\circ & \text { CPU : Intel }{ }^{\circledR} \text { Core }^{\text {TM }} 2 \text { Duo } 2.6 \mathrm{GHz} \\
\circ & \text { Main Memory : } 2.048 \mathrm{MB} \\
\circ & \text { VGA Memory : } 256 \mathrm{MB} \\
\circ & \text { Hard Disk Drive : } 76.293 \mathrm{MB} \\
\circ & \text { Network Device : TP-Link WN321G } \\
\circ & \text { Monitor LCD 17" }
\end{array}
$$

- Konfigurasi access point (AP) dengan SSID 'Onlimo3G' dan DHCP IP address kelas C 192.168.0.100 192.168.0.105 seperti contoh berikut :

$$
\begin{array}{ll}
\circ & \text { IP address : 192.168.0.101 } \\
\circ & \text { Netmask (kelas C) : 255.255.255.0 } \\
\circ & \text { Access point / SSID :ONLIMO3G } \\
\circ & \text { Default router (GW) : 192.168.0.254 }
\end{array}
$$

- Instalasi dan konfigurasi FreeBSD, MySQL Client, dan program control data logger pada USB flash disk minimal berkapasistas $16 \mathrm{~GB}$, dengan layout pembagian partisinya adalah sebagai berikut :

$\begin{array}{llll}\circ & \text { Partisi } & \text { / } & 4.0 \mathrm{~GB} \\ \circ & \text { Partisi } & \text { /var } & 2.0 \mathrm{~GB} \\ \circ & \text { Partisi } & \text { /tmp } & 1.0 \mathrm{~GB} \\ \circ & \text { Partisi } & \text { swap } & 1.0 \mathrm{~GB} \\ \circ & \text { Partisi } & \text { /usr } & 6.8 \mathrm{~GB}\end{array}$

- Konfigurasi koneksi data logger dengan AP SSID 'Onlimo3G' melalui perangkat USB Wifi.

- Kalibrasi unit multiprobe sensor melalui software hyperterminal dan memasangnya pada konektor serial RS232C unit data logger.

Untuk memastikan apakah data yang diukur oleh sensor dan dikendalikan oleh program control data logger telah dikirimkan ke dalam tabel data pada komputer server, perlu dibuat program 'cekquery', yaitu program script yang dapat menampilkan beberapa baris data terakhir. Berikut ini adalah kode sumber program 'cekquery' yang dapat dijalankan di data logger maupun komputer server untuk menampilkan beberapa baris data terakhir hasil pengukuran kualitas air yang telah masuk ke dalam database.

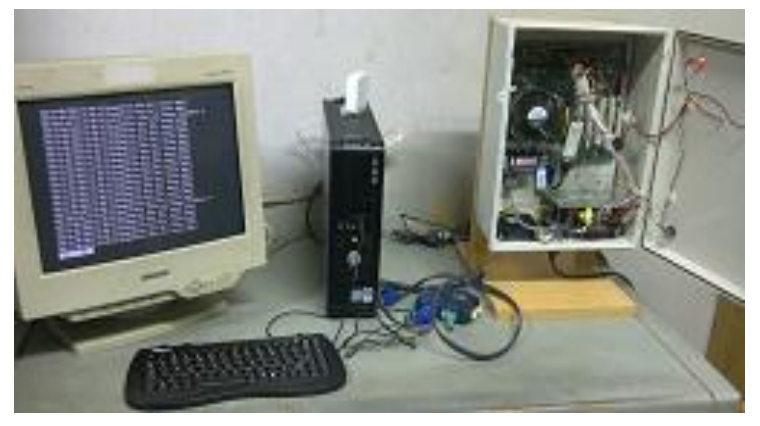

Gambar 10. Pengujian Program.

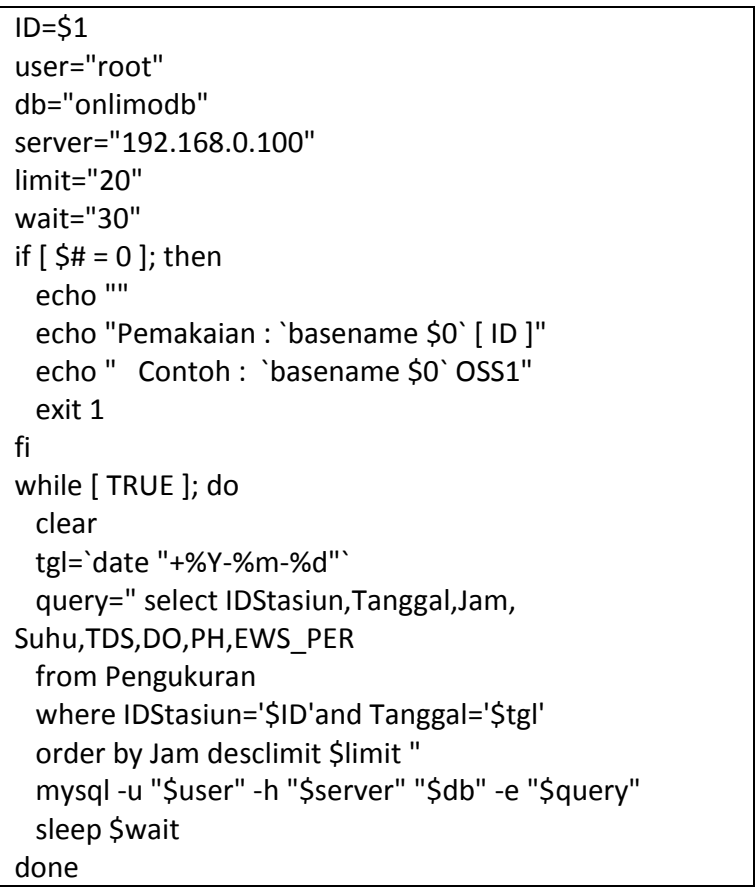

Gambar 11, berikut adalah contoh tampilan program 'cekquery'. Baris 1, 2, 3, 4, 5, 6, 7, 8 berturut-turut adalah, ID stasiun, tanggal pengukuran, jam pengukuran, temperatur, total dissolved substanced, dissolve oxygen, $\mathrm{pH}$, dan keterangan data periodik atau EWS. 


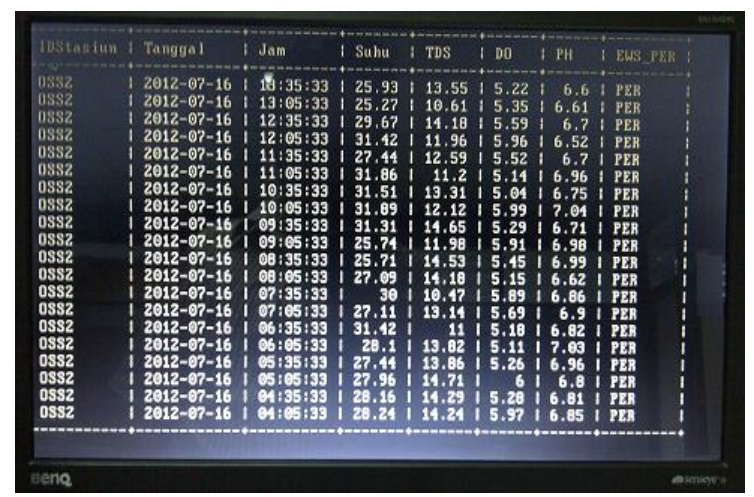

Gambar 11 : Output Program Cekquery.

\subsection{Rancangan Sistem Database}

Database untuk menyimpan data hasil pengukuran online menggunakan data logger berbasis mainboard komputer ini, terdiri dari dua tabel data dengan struktur sebagai berikut :

Tabel 4. Data Stasiun Monitoring (Wahjono, 2012)

\begin{tabular}{|l|c|l|}
\hline Field Parameter & Tipe Data & \multicolumn{1}{|c|}{ Keterangan } \\
\hline IDStasiun * & Text(8) & $\begin{array}{l}\text { Nomor Identifikasi } \\
\text { Stasiun Monitoring }\end{array}$ \\
\hline NamaStasiun & Text(100) & $\begin{array}{l}\text { Nama Stasiun } \\
\text { Monitoring }\end{array}$ \\
\hline AlamatStasiun & Text(250) & $\begin{array}{l}\text { Alamat Lengkap } \\
\text { Lokasi Stasiun }\end{array}$ \\
\hline AlamatIP & Text(50) & IP Data Logger \\
\hline KontakPerson & Text(100) & $\begin{array}{l}\text { Nama operator } \\
\text { Stasiun }\end{array}$ \\
\hline LintangDerajat & Double & $\begin{array}{l}\text { Posisi Koordinat } \\
\text { Lintang Derajat }\end{array}$ \\
\hline LintangMenit & Double & $\begin{array}{l}\text { Posisi Koordinat } \\
\text { Lintang Menit }\end{array}$ \\
\hline LintangDetik & Double & $\begin{array}{l}\text { Posisi Koordinat } \\
\text { Lintang Detik }\end{array}$ \\
\hline BujurDerajat & Double & $\begin{array}{l}\text { Posisi Koordinat } \\
\text { Bujur Derajat }\end{array}$ \\
\hline BujurMenit & Double & $\begin{array}{l}\text { Posisi Koordinat } \\
\text { Bujur Menit }\end{array}$ \\
\hline BujurDetik & Double & $\begin{array}{l}\text { Posisi Koordinat } \\
\text { Bujur Detik }\end{array}$ \\
\hline Keterangan & Text(500) & $\begin{array}{l}\text { Keterangan Lain } \\
\text { Tentang Stasiun } \\
\text { Monitoring }\end{array}$ \\
\hline Foto & Text(250) & $\begin{array}{l}\text { Nama Direktori \& } \\
\text { File Foto Stasiun }\end{array}$ \\
\hline
\end{tabular}

* Primary Key

Tabel 5. Data Pengukuran (Wahjono, 2012)

\begin{tabular}{|l|c|l|}
\hline $\begin{array}{l}\text { Field } \\
\text { Parameter }\end{array}$ & $\begin{array}{c}\text { Tipe } \\
\text { Data }\end{array}$ & \multicolumn{1}{|c|}{ Keterangan } \\
\hline IDStasiun * & Text(8) & $\begin{array}{l}\text { Nomor Identifikasi Stasiun } \\
\text { Monitoring }\end{array}$ \\
\hline Tanggal * $^{*}$ & Date & Tanggal Pengukuran (YYYY- \\
\hline
\end{tabular}

\begin{tabular}{|l|l|l|}
\hline & & MM-DD) \\
\hline Jam * & Time & $\begin{array}{l}\text { Waktu Pengukuran } \\
\text { (HH:MM:SS) }\end{array}$ \\
\hline Suhu & Double & Temperatur / Suhu \\
\hline DHL & Double & $\begin{array}{l}\text { Daya Hantar Listrik / } \\
\text { Konduktifitas }\end{array}$ \\
\hline TDS & Double & $\begin{array}{l}\text { Kandungan Zat Padat } \\
\text { Terlarut }\end{array}$ \\
\hline Salinitas & Double & Kadar Garam \\
\hline DO & Double & Kandungan Oksigen Terlarut \\
\hline pH & Double & $\begin{array}{l}\text { Kondisi Keasaman / } \\
\text { Kebasaan }\end{array}$ \\
\hline EWS_PER & Text(3) & Data EWS atau PERiodik \\
\hline * Primary Key & \multicolumn{2}{|l}{}
\end{tabular}

Kedua tabel memiliki hubungan relasi seperti gambar di bawah ini dan didefinisikan dalam bahasa SQL, yakni DDL Stasiun dan DDL Pengukuran.

Tabel Stasiun Monitoring

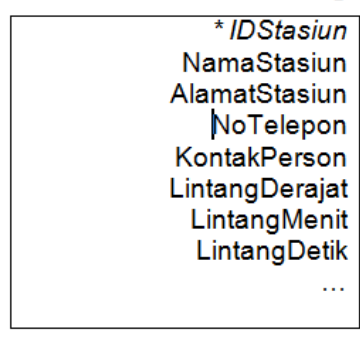

Gambar 12 : Relasi Tabel Stasiun Monitoring dan Tabel Data Online.

DDL Stasiun (Wahjono, 2012)

CREATE TABLE IF NOT EXISTS `stasiun` (

'IDStasiun' varchar(8) NOT NULL,

'NamaStasiun 'varchar(100) NOT NULL,

‘AlamatStasiun` varchar(250) NOT NULL,

'NoTelepon 'varchar(50) NOT NULL,

'KontakPerson` varchar(100) NOT NULL,

'LintangDerajat` double NOT NULL,

'LintangMenit' double NOT NULL,

'LintangDetik' double NOT NULL,

'BujurDerajat' double NOT NULL,

'BujurMenit' double NOT NULL,

'BujurDetik' double NOT NULL,

'Keterangan` varchar(500) NOT NULL,

'Foto' varchar(250) NOT NULL,

PRIMARY KEY ('IDStasiun'),

UNIQUE KEY 'IDStasiun '('IDStasiun`)

)ENGINE=InnoDB DEFAULT CHARSET=latin1;

DDL Pengukuran (Wahjono, 2012)

CREATE TABLE IF NOT EXISTS 'Pengukuran`(

"IDStasiun 'varchar(8)NOTNULL DEFAULT",

'Tanggal' date NOT NULL DEFAULT '0000-00-00',

'Jam 'time NOT NULL DEFAULT '00:00:00',

'Suhu' double DEFAULT NULL,

'DHL' double DEFAULT NULL,

'TDS' double DEFAULT NULL,

'Salinitas' double DEFAULT NULL,

Tabel Data Online

Tangga

Jam *

Suhu

DHL

Salinitas

DO

$\mathrm{pH}$

Jenis

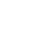


'DO' double DEFAULT NULL,

'PH' double DEFAULT NULL,

'EWS_PER'varchar(3) DEFAULT NULL,

PRIMARY KEY ('IDStasiun', 'Tanggal', 'Jam '),

UNIQUE KEY 'IDStasiun' ('IDStasiun', 'Tanggal', 'Jam')

) ENGINE=InnODB DEFAULT CHARSET=latin1;

\section{KESIMPULAN DAN SARAN}

Kegiatan pengembangan aplikasi kontrol data logger merupakan kegiatan litbang untuk menyediakan alternatif teknologi pemantauan kualitas air menggunakan komponen yang ada di pasaran. Fokus kegiatan ini lebih menitikberatkan kepada kegiatan interfacing ke perangkat sensor menggunakan bahasa pemrograman $\mathrm{C}++$. Beberapa kesimpulan yang dapat ditarik dari kegiatan ini adalah sebagai berikut :

- Untuk mengurangi biaya investasi peralatan pemantuan kualitas air, salah satunya adalah dengan mengembangkan sistem pemantuan kualitas air dengan memanfaatkan perangkat lunak sumber terbuka (free open source software/FOSS).

- Mainboard komputer dapat dimanfaatkan sebagai perangkat keras data logger untuk pemantuan kualitas air dengan bantuan program control data logger.

- Program control data logger dapat dikembangkan dengan GNU C++ yang juga merupakan development tools dari FOSS.

- Untuk mengembangkan program control data logger dimulai dengan mendefinisikan fitur yang diperlukan oleh sistem pemantuan kualitas airnya.

- Melalui metode water flow pelaksanaan diagram siklus pengembangan perangkat lunaknya dapat dilakukan secara berulang untuk memperkecil kesalahan yang ada dan melengkapi fitur yang dibutuhkan.

- Hasil ujicoba terhadap media penyimpan data memberikan hasil bahwa flash disk kelas 10 dengan kapasitas 16GB merupakan spesifikasi minimal media penyimpan ini agar dapat bekerja dengan optimal.

- Hasil ujicoba terhadap media komunikasi data memberikan hasil bahwa tidak semua perangkat USB wifi dapat digunakan pada sistem operasi FreeBSD. Beberapa perangkat USB wifi yang terdapat di pasaran dan dapat dengan mudah digunakan adalah TP-LINK TL-WN321G (versi 2.0 4.1) dan D-Link DWA-140.

- Hasil ujicoba eksekusi program pada sistem operasi FreeBSD juga memungkinkan untuk menjalankan beberapa program control data logger dalam satu unit data logger. Hal ini dapat diimplementasikan untuk pemantuan kualitas air di beberapa lokasi yang letaknya saling berdekatan dengan satu unit data logger dan beberapa unit sensor.

- Secara umum ujicoba operasi perangkat keras data logger di dalam ruangan (indoor test) memberikan hasil, bahwa perangkat tersebut dapat bekerja secara terus menerus selama kurang lebih 5 bulan.

Saran yang dapat diberikan dalam kegiatan ini adalah sebagai berikut :

- Perlu dibuatkan modul/subroutine beberapa metode pengiriman data ke pusat data, yakni :

- Melalui komunikasi http

- Melalui sistem SMS

- Prioritas penggunaan modul pengiriman di atas disesuaika dengan ketersediaan jalur akses pengiriman data.

- Jika tidak ada jalur akses langsung ke sistem database, bisa menggunakan jalur komunikasi http.

- Jika tidak ada jalur komunikasi internet, bisa digunakan jalur pengiriman menggunakan sistem SMS.

- Perlu disusun juga beberapa metode pembacaan data dari beberapa jenis sensor digital. Metode komunikasi ke sensor dibedakan dengan penyediaan opsi akses komunikasi ke sensor, misalnya :

$\begin{array}{ll}\circ & \text { opsi -ysi --> untuk sensor YSI } \\ \circ & \text { opsi -dkk --> untuk sensor DKK-TOA } \\ \circ & \text { dan lain-lain }\end{array}$

\section{DAFTAR PUSTAKA}

- Suhendar I. Sachoemar dan Heru Dwi Wahjono (2007), Kondisi Pencemaran Lingkungan Perairan di Teluk Jakarta, JAI Vol 3 No. 1, 2007, PTL BPPT.

- Curtis, G, "Business Information System. $2^{\text {nd }}$ edition". Wokingham, England: Addison Wesley, 1995.

- Syamsudin, Muharyan (1984), Sistem Telemetri

- Hungarian Ministry for Environment and U. S. Agency for International Development (1996), Basic instrumentation of monitoring station (http://www.rivermonitoring.hu).

- YSI (2011), 6 Series Multiparameter Water Quality Sondes User Manual, YSI Incorporated, Yellow Springs

- Anonymous (2012), Serial Port, wikipedia (http://en.wikipedia.org/wiki/Serial_port)

- Heru Dwi Wahjono (2012), Data Logger Onlimo OSS Berbasis Mainboard PC, Pusat Teknologi 
Lingkungan - BPPT, 2012

- Heru Dwi Wahjono (2012), Software Onlimo OSS Berbasis Mainboard PC, Pusat Teknologi Lingkungan - BPPT, 2012

- TPABLC (2012), Technical Document Pengembangan Sistem Pemantuan Kualitas Air Realtime Berbasis OSS, Pusat Teknologi Lingkungan - BPPT, 2012. 